Área Abierta. Revista de comunicación

audiovisual y publicitaria

ISSN: 1578-8393

\title{
La adaptación radiofónica de Extraños en un tren: un cruce de vías entre la novela y el filme
}

\author{
Mercedes Miguel Borrás ${ }^{1}$ \\ Recibido: 23 de septiembre de 2016 / Aceptado: 1 de diciembre de 2016
}

Resumen. La adaptación radiofónica de Extraños en un tren es un buen ejemplo de la utilización del lenguaje para explorar una narrativa propia del medio. Está basada en la novela de Patricia Highsmith e inspirada en el filme de Alfred Hitchcock, pues, aunque no figura en los créditos, sus huellas están presentes a lo largo del relato.

En este artículo nos preguntamos acerca del paisaje sonoro y de la procedencia de las imágenes sonoras de esta adaptación. Partiremos de la novela y el filme para abordar aquellos sistemas expresivos que han hecho posible la adaptación radiofónica. Nos aproximaremos a los cambios estructurales y formales producidos por la diferente sustancia expresiva (Saussure, 1973), las relaciones que mantienen con las circunstancias socio-históricas, su transtextualidad (Genette, 1989), y las migraciones de sentidos (Barthes, 1980).

El análisis de los tres textos nos permite establecer que la adaptación de Extraños en un tren consigue plasmar el universo simbólico de la novela y al mismo tiempo es subsidiaria del filme. Esta interrelación enriquece el texto al multiplicar sus sentidos.

Palabras clave: Ficción sonora, novela, cine, adaptación, transtextualidad, transcodificación, Extraños en un tren

\section{[en] The Radio Adaptation of Strangers on a Train: An Intersection Between the Novel and the Film}

\begin{abstract}
The radio adaptation of Strangers on a Train is a right example of the use of language to examine their own narrative framework. It is based on the novel by Patricia Highsmith and inspired by Alfred Hitchcock's film, whose influence in the radio adaptation is obvious.

We use the novel and the film to explore the radio expressive tools. We will approach structural and formal theories such as expressive substance (Saussure, 1973), transtextuality (Genette, 1989) and senses' migrations (Barthes, 1980).

The analysis of the three texts allows us to establish that the adaptation of Strangers on a Train manages to capture the symbolic universe of the novel and the film. This interrelation enriches the text by multiplying its senses.
\end{abstract}

Keywords: Radio drama, Novel, Cinema, Adaptation, Transtextuality, Transcoding, Strangers on a Train

\footnotetext{
$1 \quad$ Universidad de Valladolid

mmborras@fyl.uva.es
} 
Sumario. Introducción. 1. El problema de la adaptación. 2. Análisis. 3. A modo de conclusión. 4. Bibliografía.

Cómo citar: Miguel Borrás, M. (2017) La adaptación radiofónica de Extraños en un tren: un cruce de vías entre la novela y el filme, en Área Abierta. Revista de comunicación audiovisual y publicitaria 17 (1), 37-55. http://dx.doi.org/10.5209/ARAB.53565

\section{Introducción}

La dictadura de la realidad a la que está sometida la radio ha hecho que, en la mayoría de los casos, su fuerte carga expresiva ocupe un lugar secundario. Durante décadas ha quedado relegada a la nostalgia, especialmente en sus programas dramáticos. Pero, con la entrada en el nuevo milenio, estos han comenzado a experimentar una transformación ${ }^{2}$ que apuesta por el lenguaje radiofónico, reivindicando la puesta en sonido - a la manera que los cineastas de la Nouvelle vague hacían con la puesta en escena $^{3}$ - para explorar una narrativa propia del medio con la que construir los textos sonoros, creando retóricas que enriquezcan este ecosistema en el que aún queda mucho por explorar. La adaptación radiofónica de Extraños en un tren supone un buen ejemplo de ello. Esta se basada en la novela homónima de Patricia Highsmith (1950) y se inspira en el filme dirigido por Alfred Hitchcock (Strangers on a Train, 1951), que aunque no figura en los créditos está presente en sus secuencias, personajes, sonidos e imágenes. La deuda con el maestro del suspense es indudable, como trataremos de reflejar a lo largo de estas páginas.

\section{El problema de la adaptación}

La adaptación radiofónica supone transponer un texto, en principio literario, al lenguaje radiofónico, es decir, incorporar música, efectos sonoros, personajes, diálogos, narradores, encontrar, en suma, los elementos narrativos adecuados con los que construir un discurso coherente. Este es el gran reto.

La traslación literal no es posible, ya que se altera la sustancia expresiva, la naturaleza del significante (Saussure, 1973). Requiere un conocimiento en profundidad de sus elementos para transformar el texto escrito en relato sonoro sin que pierda su sentido original. En el texto literario conviven simultáneamente fuentes de naturaleza diversa, con características muy diferentes que dificultan

2 En esta senda podemos encontrar Milenio 3, una iniciativa promovida en 2003 por la Cadena Ser en la que durante doce años, se hicieron dramatizaciones. Misterios al descubierto es un buen ejemplo; y, por supuesto Ficción Sonora, un programa de RTVE que inició su andadura en 2008 y prosigue en la actualidad con la intención de recuperar los programas dramáticos en la radio. Se emite en Radio 3 y sus obras se representan en directo en La Casa Encendida, en Madrid. La adaptación cinematográfica de Extraños en un tren forma parte de este programa.

3 Reunidos en torno a la Revista Cahiers du cinema, entre los años 50 y principios de los 60, sus fundadores defendían el cine como lenguaje y criticaban las adaptaciones que se estaban haciendo en su país al considerarlas meras ilustraciones de textos. 
su ensamblaje, pero al mismo tiempo lo enriquece. La adaptación radiofónica trata de recrear el ambiente que envuelve a las personas en distintas perspectivas acústicas, configurar un paisaje sonoro (Schaeffer, 2013), ese conjunto de sonidos que envuelven el ambiente y su significación, es decir, la sonosfera ${ }^{4}$. Entender que la percepción de sonidos en su totalidad es superior a la suma de las partes es esencial, pues su significación es el resultado de la codificación de sus sistemas expresivos música, efectos, palabra-. Y en este sentido es fundamental la creación de imágenes sonoras $^{5}$, ya que permiten reconstruir la escena creada a través de la narración.

La radio emerge como la eterna compañera para dibujar nuestros sonidos cotidianos y evocar los imaginarios [...]. Puede despertar la imaginación y hacernos pasear por lugares ignotos, transmitir sentimientos profundos, transitar por el tiempo (Rodero, en Romo, 1997: 136).

La creatividad está íntimamente unida a la imaginación, y la radio es un instrumento muy poderoso dada su capacidad para convocar universos imaginarios, condición sine qua non del sonido; estamos hablando de imágenes auditivas.

¿Cómo se ha creado ese paisaje sonoro en la adaptación radiofónica de Extraños en un tren? ¿De dónde proceden sus imágenes? ¿En qué medida se nutre del filme?

Decía André Bazin que «la buena adaptación cinematográfica debe llegar a restituir lo esencial de la letra y del espíritu» (1990: 116). No hay duda de que Hitchcock se sumerge perfectamente en el universo de la escritora ${ }^{6}$ y esto se deja sentir en la adaptación radiofónica contribuyendo en la construcción de imágenes ${ }^{7}$.

Es nuestro propósito estudiar los cambios estructurales y formales producidos por la diferente sustancia expresiva -la transcodificación-. Pero también tendremos en cuenta las relaciones que mantienen con las circunstancias socio-históricas, su transtextualidad (Genette, 1989), es decir, todo lo que pone al texto en relación manifiesta o secreta con otros textos.

La novela de Patricia Highsmith fue publicada en 1950, un año después Alfred Hitchcock la adaptaba al cine. Para la escritora era su primera novela; el cineasta ya contaba con más de treinta películas ${ }^{8}$. La adaptación radiofónica llega sesenta años después, realizada por Mayca Aguilera y con guion de Alfonso Latorre.

4 El concepto «paisaje sonoro» fue definido en 1973 por Murray Schafer. El término «sonosfera» fue acuñado por el etnomusicólogo Gonzalo Camacho (Flores Mercado 2014:196); proviene de la «semiosfera», definida por Yuri Lotman como el entorno de signos en el que vivimos que, con la introducción masiva de los medios audiovisuales, Cohen-Seat denominó «iconosfera».

5 El concepto «imagen sonora» fue enunciado en 1878 por Saussure en Memoria sobre el sistema primitivo de vocales en lenguas indoeuropeas.

6 El concepto «imagen sonora» fue enunciado en 1878 por Saussure en Memoria sobre el sistema primitivo de vocales en lenguas indoeuropeas.

7 A esto podríamos añadir que gran parte de los oyentes tienen alojadas en su memoria las imágenes del filme de Hitchcock: «Los materiales derivados del texto fuente al ser leídos en un contexto o período diferente son actualizados en procesos inherentes en la recircunstancialización que necesariamente tiene lugar» (Chávez, 2016:16).

8 Amén de la repercusión que ha tenido el filme desde su estreno - fue la mayor recaudación de Hitchcock en la Warner Bros-, ha sido objeto de diferentes adaptaciones. En 1951, la CBS estrena una adaptación radiofónica en cuyos créditos figura «adaptación radiofónica del filme de Hitchcock», reestrenándose tres años después. En 1969 se hizo una versión del filme, Once your kiss a stranger, fuente de inspiración para la comedia Tira a mamá del tren (Danny DeVito, 1987) y una película para televisión, Extrañas en un tren (1996). 
A lo largo de estas páginas analizaremos los tres textos. Partiremos de la novela -texto fuente- y el filme -hipertexto- para acercarnos a aquellos sistemas expresivos que hacen posible la adaptación radiofónica. Trabajaremos en los aspectos narrativos, la construcción de imágenes, y las migraciones producidas en su transtextualidad; estableciendo algunas de las consecuencias que tienen tales operaciones en la producción de sentido (Chávez, 2016).

\subsection{Contexto histórico-social}

Después de la Segunda Guerra Mundial Estados Unidos y la Unión Soviética comenzaron a repartirse el mundo en territorios bajo su influencia. El feroz anticomunismo que se desató en el país americano propició que muchos ciudadanos de tendencia progresista o demócrata fueran represaliados por el Comité de Actividades Antiamericanas liderado por el senador republicano Joseph McCarthy. Las opciones ideológicas enfrentadas que habían provocado la Guerra de Secesión entre el Norte y el Sur seguían vigentes a mitad del siglo XX. Nueva York representaba la cima de las ideas culturales avanzadas y las costumbres sociales. En contraposición a esta realidad, Texas y en general los estados del Sur defendían los valores tradicionales de la familia, la segregación racial y el conservadurismo protector de los intereses de clase.

Figuras de la música, como Frank Sinatra, eran en las zonas más desarrolladas sinónimo de lujo, sofisticación y modernidad. Mientras, en un Sur carente de infraestructuras, triunfaba la sencilla música country de Hank Williams y otros artistas, que hablaban de historias cotidianas en la inmensidad del medio rural.

Si había en el ambiente una desatada persecución anticomunista, los prejuicios de clase no eran menos devastadores. Los que gozaban de una posición económica privilegiada, acompañada de un comportamiento individual más libérrimo, frecuente en los barrios exclusivos de Manhattan y las mansiones residenciales de la alta sociedad en la costa, despreciaban el provincianismo sureño y la represión civil que llevaban a cabo las religiones más conservadoras.

\subsection{La imagen poética}

Novela, filme y ficción sonora son hechos del lenguaje, manifestaciones del discurso, pero no marcado, abierto a múltiples sentidos. Son instancias narrativas, abordan la ficción por medio de capítulos o secuencias, focalizan la atención a través de un narrador y personajes que trasladan al lector-espectador-oyente a un espacio y tiempo imaginarios. Un discurso, pues, volcado a su dimensión artística que se despliega en múltiples voces, todas me hablan pero ninguna es capaz de garantizar la verdad (Miguel Borrás, 2008). Un juego producido en las relaciones sintagmáticas y paradigmáticas que se establece entre las palabras, imágenes y/o sonidos, que las lleva a alejarse de su uso cotidiano y que en su articulación les confiere su carga estética. Es ese exceso de material significante (Jakobson, 1985) presente en todo lenguaje el que expresa su poética. Eso que el lector reconoce como literario. La imagen o figura literaria es el espacio de juego para el artista, mundo auxiliar, germen de su universo 
poético (Miguel Borrás, 2008) ${ }^{9}$. Afirma Alexandra Álvarez Muro que poética es una voz polisémica. Poética con mayúscula se entiende como disciplina de la estilística, conjunto de principios o reglas que rigen un género discursivo; también es una de las funciones del lenguaje que permite al texto volcarse sobre sí mismo y jugar con las palabras y los sonidos para construirse. Por último, se entiende poética como la poesía o lo poético, como todo lo que tiene intencionalidad estética, la expresión de la belleza a través de la palabra, manifestado frecuentemente en poemas (Álvarez Muro, 2008: 10).

Estamos hablando de la función textual, constructora de enunciados, esa poética creadora de nuevos sentidos y universos imaginarios expuesta por Jakobson (1985), retomada y descrita posteriormente por Halliday y Hassan (1990).

Aludimos al concepto de poética precisamente por la singularidad estructural que se produce en los textos narrativos, por su alta capacidad connotativa, en los que convergen rasgos poéticos y lingüísticos, que su articulación les confiere una singularidad estructural (García Berrio, 1994). Del mismo modo que un texto escrito puede poseer múltiples referencias visuales y sonoras, un texto audiovisual o un texto sonoro también produce figuras literarias. Texto escrito, visual y sonoro caminan entrelazados. No hay una imagen puramente icónica (Gauthier, 1996), para su total entendimiento necesita de las palabras y/o sonidos; pero al mismo tiempo, las palabras y los sonidos están cargados de imágenes.

\subsection{Texto narrativo como proceso de significación}

A lo largo de estas páginas nos adentraremos en la construcción narrativa de estos textos, para encontrar la expresividad producida en ese flujo-cruce entre la puesta en escena y la puesta en sonido ${ }^{10}$, es decir, la transcodificación (Genette, 1989); esto nos permitirá analizar cómo se ha efectuado y los problemas que plantea su elaboración.

Trabajamos el texto narrativo, siguiendo a los neoformalistas (Propp, Todorov, Kristeva), como proceso de significación: los personajes y las acciones con las que se construyen las secuencias, los sentidos, los códigos culturales, los enigmas y su resolución; el universo simbólico, en suma ${ }^{11}$. Pero no se trata de establecer una lista a

9 Amén de la repercusión que ha tenido el filme desde su estreno -fue la mayor recaudación de Hitchcock en la Warner Bros-, ha sido objeto de diferentes adaptaciones. En 1951, la CBS estrena una adaptación radiofónica en cuyos créditos figura «adaptación radiofónica del filme de Hitchcock», reestrenándose tres años después. En 1969 se hizo una versión del filme, Once your kiss a stranger, fuente de inspiración para la comedia Tira a mamá del tren (Danny DeVito, 1987) y una película para televisión, Extrañas en un tren (1996).

10 Estamos hablando de esas múltiples voces en las que se despliega el texto artístico y que son las que le otorgan carta de naturaleza. En el caso del cine, que sintetiza las estructuras del teatro y la novela (Morin, 1972), estaría formada por signos -icónicos, gestuales y verbales- y sus articulaciones discursivas -montaje, movimiento interno, movimiento de cámara-. En la ficción sonora estos sistemas expresivos se pueden sintetizar en la voz (el narrador y los diálogos), los personajes -que asumen las características físicas y psicológicas-, la música, los efectos, el silencio, y sus articulaciones discursivas, generadas mediante el montaje y los planos sonoros.

11 En S/Z (Barthes 1980), un minucioso análisis sobre el relato de Bazac, Sarrasine, Roland Barthes enuncia que en todo relato se pueden dar cinco grandes códigos: hermenéutico -se plantea y se retrasa un enigma-; sema -significado connotativo al que remite-; simbólico - multivalente, reversible-; proairético -acciones y comportamientos que dan lugar a secuencias-; cultural - del saber, o de referencias-. 
seguir, sino de «escuchar las voces con las que está tejido el texto [...] su concurrencia deviene escritura» (Barthes, 1980: 14). Esto nos permite efectuar el análisis desde diferentes niveles textuales: las transformaciones producidas en la adaptación y la poética presente en la propia naturaleza del discurso literario, cinematográfico y radiofónico, es decir, donde radica ese exceso de material significante que confiere a cada uno su fuerza expresiva. Ese exceso lo encontraremos en su diégesis, es decir, la construcción imaginaria del universo ficticio, sus códigos y símbolos: «Todo texto se construye como mosaico de citas, es absorción y transformación de otro texto» (Kristeva, 1997: 3).

No hay duda de que la abundancia de construcciones retóricas y figuras poéticas enriquecen el discurso, pero también dificultan la transducción a una dimensión sonora y, sobre todo, si se pretende ser fiel al texto fuente. Existe una gran dificultad para encontrar las alternativas idóneas para construir una narración sonora que refleje ese universo simbólico. La ausencia de toda referencia visual hace complicada la construcción de personajes, y la evolución espacio-temporal de las escenas requiere de unas estrategias discursivas que ponen en juego retóricas en la mayoría de los casos olvidadas o dejadas en un plano totalmente secundario. El espacio sonoro sugerido tiene una gran capacidad connotativa, pero el espacio narrativo encarna dimensiones sensoriales diferentes. Es una síntesis de figura y fondo» (Balsebre, 1994: 151).

Podríamos utilizar la radio como mero transductor de un medio a otro (alguien lee un texto literario a través de la radio), pero hablamos de un lenguaje específicamente radiofónico, es decir, formado por signos sonoros y articulaciones discursivas montaje, planos, movimiento de los actores-. Se trata, como venimos diciendo, de una instancia narrativa $\mathrm{y}$, como tal, el espacio y el tiempo son ejes fundamentales sobre los que se sustenta y construye su universo diegético.

\section{Análisis}

Efectuamos un análisis pormenorizado de los tres textos que nos permitirá establecer cómo se producen los flujos de sentido presentes en la ficción sonora, que se nutre de la novela ${ }^{12}$ (texto fuente o hipotexto) y el filme (hipertexto). No hay ninguna duda que existe una denodada intención de fidelidad hacia el original literario, ambas adaptaciones respetan la línea argumental y participan de una misma estructura.

Guy y Bruno ${ }^{13}$, dos jóvenes cuyas vidas son aparentemente diferentes, se cruzan en un tren. Durante el largo viaje vamos descubriendo que ambos están unidos por un mismo destino que les impide alcanzar sus deseos. Bruno pretende disponer del dinero que su autoritario padre le restringe, y Guy quiere casarse con Anne, ya que su esposa (Miriam) no le concede el divorcio. Bruno propone a Guy un intercambio de crímenes, un pacto secreto. Aunque esta idea le parece descabellada, cuando Bruno la lleva a cabo, vemos cómo la muerte de su esposa le está aportando

12 Las citas de la novela de Patricia Higsmith a las que se hace referencia a lo largo de este análisis corresponden a la edición de 1986, publicada por la editorial Anagrama.

13 Para evitar confusiones, respetamos los nombres de los personajes de la novela, tanto cuando nos refiramos al filme, como a la ficción sonora. 
pingües beneficios. Cuestión que se plantea como terrible pero, al mismo tiempo, moralmente justificable. Bruno permite la escenificación de los deseos ocultos de Guy, que luchan por salir.

Pero la adaptación literal no es posible, ya que se altera la naturaleza del significante (Saussure, 1973). Es esta naturaleza la que nos va a servir para emprender el análisis, estudiando los rasgos morfológicos y semánticos a través de sus unidades funcionales (Barthes, 1970). Pero no por ello dejaremos de tener en cuenta las marcas referenciales producidas por el contexto histórico en el que se producen y son leídas, que sitúan a los tres textos en un mismo espacio y tiempo diegético: Estados Unidos, 1950. Si bien la novela y el filme se producen en un tiempo similar, 1950 y 1951 respectivamente, la adaptación radiofónica lo hace 60 años después, en 2011.

\subsection{Procesos de significación}

Con el propósito de establecer si la ficción sonora consigue plasmar el universo simbólico de la novela y en qué medida es subsidiaria del filme, partiremos del texto fuente en busca de esa sustancia expresiva que el filme ha hecho posible -los signos y sus articulaciones discursivas-, buscaremos el fluir de sentidos que se produce en el cruce entre ambos textos.

Para atender a ese fluir de sentidos entre el texto fuente y sus adaptaciones, detenemos nuestra atención en el planteamiento ${ }^{14}$. Se abre un enigma (código hermenéutico) -el pacto que propone Bruno a Guy- y con él aparecen los deseos ocultos; se plantea el conflicto, evidenciando la realidad de los protagonistas, y queda (parcialmente) resuelto con la muerte de Miriam y, con ella, el encuentro con la verdad.

En consecuencia, partiendo de la novela, abordamos nuestro análisis desde las tres unidades que se producen en su articulación: los deseos ocultos (primera unidad), el encuentro con la realidad (segunda unidad) y el encuentro con la verdad (tercera unidad). Cada una de ellas se corresponde con una función cardinal que abre una alternativa al discurso, aunque siempre tendremos en cuenta las migraciones de sentido. No podemos olvidar que cada punto del relato irradia en varias direcciones a la vez, provocando nuevos sentidos y, por ende, nuevas lecturas (Barthes, 1980: 10).

\subsection{Primera unidad: los deseos ${ }^{15}$}

Señala Patricia Highsmith (1986: 61) que la primera página de una novela es fundamental, ya que hace que el lector se introduzca en el relato, algo crucial también en Alfred Hitchcock, quien considera que en los primeros minutos se tiene que dar lo esencial del filme (Truffaut, 1974).

14 En términos narrativos, el planteamiento es la parte inicial de un relato; está definido el tema y el tono, así como presentados los personajes, escenarios y conflicto. En la novela el planteamiento abarca hasta el capítulo 12; en el filme, 27 minutos (duración: 90 minutos), en la ficción sonora, 28 minutos (duración 74 minutos).

15 Función: abrir un campo semántico inmerso en la paradoja. Acciones: presentar los personajes y el conflicto. 
a) Presentación: (capítulo 1)

La novela arranca como si de un mecanismo de cajas rusas se tratara: un narrador, en tercera persona, asume el relato introduciéndonos en la historia (voz del discurso), para desdoblarse en una voz subjetiva que accede a los pensamientos del personaje e inmediatamente cuestiona sus palabras. De este modo, presenta diferentes temas entrelazados que sitúan el discurso en una paradoja: el bien y el mal como dos fuerzas que chocan, pero condenadas a convivir. Ya desde las primeras líneas se apunta en esta dirección: «El tren avanzaba impetuosamente con ritmo furioso... parecía embestir la pradera... pero el avance apenas se notaba... Cuanto más rápido iba el tren, más vivaces y burlonas eran las ondulaciones»».

Con esta frase se inicia el campo semántico que anuncia la estructura simbólica que envolverá al texto: la paradoja. La fuerza del tren, la quietud de la pradera, signos antónimos enunciados por el narrador que dan paso a la voz interior de Guy que, en consonancia, se mueve en esa dualidad señalando hacia el conflicto, el problema que tiene con su esposa: «Guy desvió la mirada de la ventanilla y se retrepó en el asiento... ¿Llegaría Miriam a concederle el divorcio alguna vez?». Y al describirla, la pradera vuelve a estar presente: «Podía sentir su sonrosado y pecoso rostro, irradiando una especie de calor malsano como el de la pradera al otro lado de la ventanilla. Hosca y cruel».

Estos pensamientos le conducen a una acción que incide en la intención transgresora del personaje. Guy siente deseos de fumar y, aunque está prohibido, lo hace, pero ocultándose (sema asociado a su comportamiento burgués), mientras insiste en la imposibilidad de conseguir el divorcio debido a su falta de recursos: «Miriam podría crear una campaña difamatoria en Metcalf». En este momento aparece Bruno en el compartimento, cuando están llegando a Texas. Código cultural asociado a los valores tradicionales y a la segregación racial, que se va a ir dispersando a lo largo del texto.

Esta unión de la voz interior de Guy, sus contradicciones, su tormento, precedida por el narrador, que sitúa la acción en un contexto, marcándolo semánticamente con diferentes situaciones guiadas por la antonimia (riqueza-precariedad, eleganciadesfachatez, luz-oscuridad, estrepitoso ruido-silencio), nos conduce a la paradoja, eje central del discurso. Es ese narrador desdoblado quien asume esta figura.

\section{b) Conflicto (capítulos 1 y 2)}

La antítesis es el combate entre dos plenitudes enfrentadas ritualmente como dos guerreros armados: es la figura de la oposición dada, eterna, eternamente recurrente, la figura de lo inexpiable... todo intento de atravesar el muro de la antítesis constituye una transgresión [...] la paradoja es la última tentativa del código para someter a lo inexpiable (Barthes, 1980: 21).

La presencia de Bruno, al que Guy describe «con los ojos inyectados en sangre» $\mathrm{y}$ «un enorme grano en la frente», le saca de sus oscuros pensamientos acerca de Miriam, estableciendo así la primera asociación entre ambos personajes, pero también con el libro de Platón -luego sabremos que se trata de Los diálogos-, que intenta leer cuando Bruno se sienta a su lado y que piensa no le servirá de nada cuando vea a Miriam. Código cultural de gran importancia semántica en el relato. $\mathrm{Su}$ presencia se hace palpable con la llegada de Bruno, como si abriera su contenido, 
otorgándole sentido. Después lo dejará olvidado en el vagón de Bruno y será la excusa para que éste le escriba. Esa anunciada antítesis adquiere toda su significación en el compartimento privado de Bruno donde se abre un código semántico: el conflicto de clases, y se plantea un enigma, el pacto secreto.

Guy desprecia a Bruno, pero sus pensamientos lo asocian con Anne, a quien adora: es de clase alta y al igual que ella vive en la exclusiva Long Island; toma el whisky que este le ofrece, le desagrada pero «su sabor le recordaba a ella». Este espíritu contradictorio del personaje se deja sentir en cada una de las acciones. Rechaza el marcado alcoholismo y odio inherente en Bruno, «el desesperado aburrimiento de los ricos»y, sin embargo, parece verbalizar sus pensamientos. Cuando Guy piensa que «con el Proyecto del Palmira Club se acabaría la desagradable conciencia de tener menos dinero que Anne», Bruno compara a Miriam «con ese grano que le ha salido en la frente, producto del odio que debe extirpar.... Las mujeres de esa clase merecen morir». Catálisis que despierta una tensión semántica en el discurso suspendiendo el relato hasta que aparece el enigma: Bruno propone un pacto secreto, el intercambio de asesinatos. Guy, observándolo, desprecia sus acciones: «sus manos manchadas de nicotina daban palmadas y se agitaban sobre las rodillas». Pero las palabras de Bruno parecen contestar a sus quimeras: «un par de coartadas a prueba de bomba, ¡la mejor idea de toda mi vida! ¿No lo ve?». Bruno introduce un cambio en la vida de Guy, deja salir sus deseos ocultos, y este cambio se va haciendo presente a lo largo de esta unidad, hasta que olvida el libro de Platón en el compartimento: «la costumbre hizo que al acostarse se acordara de su libro. Su Platón. No le gustaba la idea de que el libro pasase toda la noche en el compartimento de Bruno... ni pensar en que podía tocarlo y abrirlo».

Como los prisioneros de la alegoría de la caverna platónica, Guy ve el mundo a través de las sombras y Bruno escenifica esa verdad que la sociedad a la que él aspira oculta bajo el manto de las apariencias. Bruno destapa sus deseos, como una caja de truenos, haciéndolos estallar.

\subsubsection{El filme}

a) Presentación

Es en la paradoja, acorde con el universo simbólico de la novela, desde donde se construye la adaptación cinematográfica. Este campo semántico abierto por el narrador desdoblado que expone y cuestiona los pensamientos de Guy, es trasladado en el filme apoyando su discurso en lo que se oculta tras las apariencias.

Dos taxis llegando a la estación de trenes de los que descienden dos hombres (sólo vemos sus zapatos, unos extravagantes, de dos colores; los otros, elegantes, grises) que siguen al mozo portando sus maletas. Después el tren avanza veloz hacia un cruce de vías y en el vagón, debajo de una mesa, los zapatos de estos dos hombres chocan. Estas tres acciones inauguran el filme y con ellas su inmersión en el universo simbólico del texto fuente.

\section{b) Conflicto}

Se estructura en dos partes claramente diferenciadas para incidir en ese juego entre las apariencias y la realidad que otorga sentido al filme. Pues, lo que empieza con un choque casual entre dos pies - precedido por el cruce de las vías del tren y los 
zapatos-, provocando la conversación de Bruno y Guy en el vagón, se transforma en la imagen del desasosiego.

La puesta en escena sigue el devenir del relato en una progresión dramática ascendente: el pausado ritmo de una conversación aparentemente normal -una planificación clásica, en plano contra-plano- muestra la admiración que Bruno siente por Guy, un famoso tenista. Sema que adquiere diferentes funciones a lo largo de esta unidad dramática y alcanza su sentido con la resolución del enigma. Bruno sabe todo de él, incluso conoce sus problemas familiares, pues al ver la dedicatoria de su mechero reconoce las letras «A G, de Anne a Guy», le dice. Este mechero, que deja olvidado y que después le caerá de su bolsillo durante el asesinato, será la excusa para volver a ponerse en contacto con Guy.

Con la llegada al compartimento privado de Bruno, la puesta en escena se va haciendo más expresiva: el traqueteo y el silbato del tren, el rostro de Guy desviando su mirada hacia la ventana. Finalmente ese silbato subraya las frases de Bruno que no cesa de beber y hablar llamando la atención sobre su importancia semántica «soy su amigo, haría lo que fuera por usted», lo que contribuye a crear la imagen del desasosiego de Guy. Para alcanzar su punto álgido (detonante) en la catálisis ya mencionada en la novela -a saber, «las mujeres de esa clase merecen morir»- que da paso al enigma, el pacto propuesto por Bruno - «un asesinato por delegación»-, mientras el sonido de las campanas de la estación encadena con el del silbato del tren que sube a primer plano subrayando sus palabras. Después Guy intenta salir del compartimento (la cámara sigue su movimiento), pero Bruno se levanta e insiste (ahora unidos en un plano contrapicado): «será un asesinato por delegación, no lo olvide». Finalmente, Bruno se queda solo y observa el mechero que Guy ha dejado olvidado sobre la mesa; el silbato del tren sube a primer plano señalando hacia ese destino fatal hacia el que conduce este viaje, mientras Bruno cogiendo el mechero sonríe diciendo: «entrecruzados».

\subsubsection{La Ficción sonora}

Un narrador y un programa de radio son el hilo conductor que nos guía por el devenir del discurso, circunstancia que va a acompañar durante toda la ficción sonora. El narrador conduce espacio-temporalmente el relato; el programa de radio, a través de la música y los comentarios del locutor, contribuye en la creación de una atmósfera visual -refleja los diferentes ambientes-, abriendo una tensión semántica en el discurso, contribuyendo así a mantener el contacto con el oyente.

a) Presentación

Las primeras marcas referenciales muestran una indiscutible intención por encuadrar el relato en una época e incidir en la separación del personaje -en este caso Bruno- con el entorno, conduciendo al oyente hacia un universo inmerso en la paradoja, acorde con el texto fuente.

Siguiendo la estructura del filme, elude las preocupaciones de Guy y sitúa la acción en la estación de tren. A través de un programa de radio, la voz de Frank Sinatra (primer plano) cantando The Continental da paso al locutor que, con tono dinámico, señala: «Buenos días a Nueva York, hoy es 10 de junio de 1950». La jovialidad que refleja el locutor del magazine encadena con las voces de la estación para dar 
paso a Bruno en el andén preguntando al revisor, mientras saluda a una azafata que llega apresuradamente y pisa sin querer a Bruno; éste enfadado la recrimina. Su voz aseverativa, expresión de desprecio, contrasta con la exclamativa del revisor y la azafata. Signos que, metonímicamente, van mostrando con tono alegre el despertar de un nuevo día, y se contraponen con una voz atildada despreciativa, que en su conjunto contribuye a expresar los prejuicios de clase del protagonista.

\section{b) Conflicto}

Reproduce con fidelidad los diálogos del texto fuente, ayudados por la música y los efectos sonoros que van entrelazados para incidir en el choque producido en el encuentro entre Bruno y Guy, tan diferentes aparentemente, unidos por el destino.

Diálogos, música y efectos en su interrelación van construyendo el discurso. Apoyando las acciones de Bruno para marcar su acusado alcoholismo: sus palabras siempre están acompañadas por los sorbos o el líquido del whisky al caer en el vaso. Anticipándose al conflicto: cuando Bruno, sirviéndose un whisky, le pregunta por su esposa, el traqueteo del tren sube a primer plano. Suspendiendo el sentido para apoyar la catálisis: «Zorras, todas merecen morir». Tras estas palabras de Bruno, la música (extradiegética) sube a primer plano y encadena con el traqueteo del tren. Y, consecuentemente, conduciéndonos hacia el enigma, el crimen perfecto: "Será un asesinato por delegación», señala Bruno; la música se intensifica y ahora encadena con el silbato del tren que se prolonga, como única fuente sonora, señalando hacia ese destino fatal hacia el que les conduce este viaje. Y esta imagen, creada a través de la música y los efectos sonoros, nos envuelve en la atmósfera del filme.

\subsection{Segunda unidad: La realidad ${ }^{16}$}

a) Desencuentro (Guy-Miriam) (capítulo 3)

Un campo de deportes, vacío y solitario, es el escenario escogido por Miriam para la cita. Sema que remite a un pasado en el que ambos fueron felices y que ahora contribuye a mostrar ese rechazo de Guy hacia su pasado y se hace patente a través de la conversación -Miriam se niega a concederle el divorcio y le chantajea-, que se va alternando con la voz interior de Guy, mostrando sus miedos - «cuando la vio, su corazón empezó a latir más fuerte»-, reproches -«como siempre, llegaba tarde... andaba con su paso acostumbrado, sin darse prisa»-, contradicciones -el asco hacia Miriam y toda esa gente que la rodeaba... y el desprecio por haberla amado-, y la angustia que le provocaba tener que ser su marido mientras ella da a luz al hijo de otro hombre. Signos que en su conjunto crean la imagen del desencuentro y que abren una tensión semántica en el discurso, provocando el retorno de las palabras de Bruno como un eco al lector y, consecuentemente, la complicidad con Guy en el desprecio hacia Miriam. De este modo Bruno y Guy, aparentemente tan diferentes, quedan unidos ante el desprecio y los prejuicios de clase. Una concatenación de acontecimientos que subrayan este sentido.

16 Función: Conocer la realidad de los protagonistas y con ella, implicar al lector-espectador-oyente, haciéndole partícipe del desprecio hacia Miriam y los beneficios del Pacto. Acciones: El desencuentro de Guy con Miriam y la unión con Bruno. 
b) Unión (Guy-Bruno) (capítulos 4, 5, 6 y 7)

Articulados con una estructura similar, presentan a Bruno y Guy en un entorno familiar necesitado de un cambio. La preocupación tanto de la madre como de la novia de Guy (capítulos 4 y 5). La relación infantil que Bruno -es la primera vez que accedemos a su punto de vista- mantiene con su madre, y el odio que siente hacia el padre (capítulo 6), son indicios que nos conducen hacia el conflicto principal, cuando Bruno se introduce en la realidad de Guy -con un telegrama y una llamada telefónicapara recordarle el pacto que hicieron en el tren (capítulo 7). Inmediatamente, otra llamada anuncia a Guy el aborto de su esposa, lo que le hace pensar: «en una semana Miriam no tendrá el más mínimo derecho sobre mí». Pero ya es demasiado tarde, Bruno ha tomado una decisión: ir en busca de Miriam (capítulos 10 y 11) y asesinarla (capítulo 12). La paradoja irrumpe constantemente en el discurso, dejando a Guy sin justificaciones morales, al igual que al lector, que ahora es su cómplice.

\subsubsection{El filme}

a) Desencuentro (Guy-Miriam)

Esta alternancia entre la voz interior del personaje, los diálogos y el escenario vacío, imagen del desencuentro con el que la novela logra que participemos de las quimeras de Guy, en el filme se logra a través de una detallada construcción del punto de vista.

Sitúa la acción en una tienda y articula el discurso a través de la mirada de los clientes atentos a la discusión de la pareja. Alertados se protegen en un despacho impidiendo así que se escuchen sus gritos, pero no la violencia del momento, ya que Guy está zarandeando a Miriam y sale estrepitosamente dando un portazo mientras ella grita: «Voy a tener a mi hijo, no me tirarás como a un zapato viejo. Te arrepentirás». Los clientes observan escandalizados, todo parece culpabilizar a Guy, exceptuando al espectador que está totalmente identificado con lo injusto de la situación.

b) Unión (Guy-Bruno)

Tres escenas encadenadas expresan esta unión de Guy y Bruno en el desprecio y los prejuicios, haciendo partícipe al espectador, pero al mismo tiempo, como ocurre en la novela, cuestionándolo.

Tras el encuentro con Miriam, Guy habla con Anne (off) en una cabina junto a la estación. Está furioso. «Me gustaría partirle el cuello», dice. El traqueteo del tren (off) impide escuchar sus palabras. Guy mira hacia afuera, el tren está pasando veloz por la estación y, elevando la voz señala: «Podría estrangularla». 


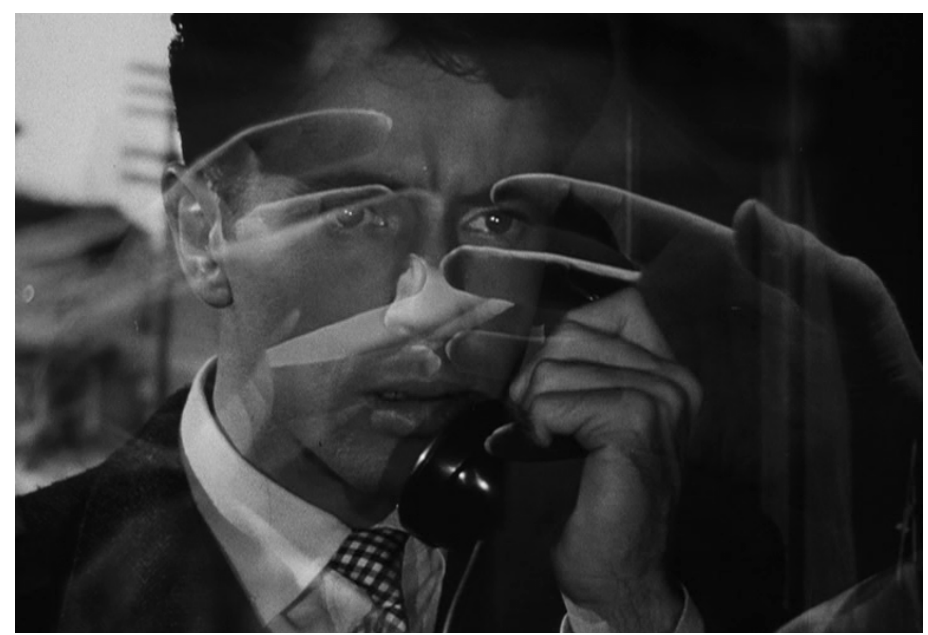

Imagen 1. Las manos de Bruno se encadenan con el rostro de Guy.

Sobre su rostro se sobreimpresionan unas manos abiertas, unidas por las muñecas, que parecen estrangular. Se trata de Bruno, sentado junto a su madre que le está haciendo la manicura: "Quiero que me queden muy bien», le dice. Después llama a Guy, despreciando a su padre que acaba de llegar y quiere hablar con él. Esta llamada, indicio de un destino fatal cuya resolución está próxima, abre una brecha incidiendo en la paradoja, haciendo que dudemos de la naturaleza de sus planes, pero al mismo tiempo que participemos de ellos: Bruno recuerda a Guy (off) los beneficios del trato, mientras al fondo su padre insiste a su esposa en la conveniencia de encerrarlo en un psiquiátrico.

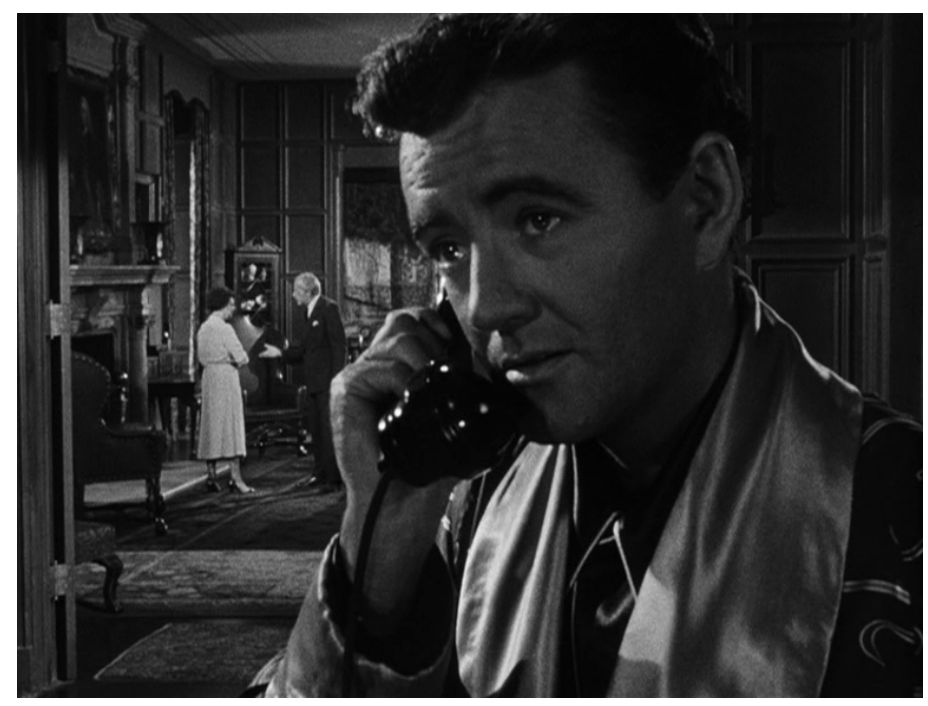

Imagen 2. Bruno habla por teléfono con Guy, al fondo sus padres. 
Bruno baja del tren en la estación de Metcalf. Dos imágenes concitan nuestra atención, una por sobreimpresión -las manos encadenadas con el rostro de Guy-y la otra en el interior del plano -Bruno al teléfono y al fondo sus padres-. Así, pese a que el filme elide el aborto de Miriam, el discurso incide en el mismo sentido, a saber, la delgada línea entre el bien y el mal, el abismo que separa los deseos de la realidad, o mejor dicho, de la verdad.

\subsubsection{La ficción sonora}

a) Desencuentro (Guy-Miriam)

En consonancia con la lógica del discurso, un narrador sitúa la escena señalando el paso de tiempo, y un programa radiofónico lo enmarca dramáticamente. La acción, al igual que el filme, tiene lugar en un espacio público, Café Coyote, al que también accede y sale dando un portazo Guy.

La voz de la locutora presenta un caluroso nuevo día mientras se escucha un tema de Hank Williams, código cultural que marca el ambiente rural de los estados sureños, y que se encuentra totalmente alejado del swing de The Continental y la voz de Sinatra, signo de modernidad, cuyas connotaciones nos remiten a las aspiraciones de Guy. El programa de radio - la locutora, la música country-y la tensión ascendente de los diálogos crean esa imagen de la violencia y el desencuentro. La voz de la locutora da paso al diálogo entre ambos cuyas voces marcan una tensión ascendente que conduce a la inevitable ruptura. Después, tras el sonoro portazo de Guy, la música sube a primer plano, mientras la locutora presenta: «Hank Williams con Why Don't You Love Me, que Alfred dedica a su chica, a quien pide perdón». Y dirigiéndose a los oyentes pregunta: «Y a ti ¿qué es lo que te dicta el corazón?». Estas palabras que abren y cierran la escena, apoyada por la música, despiertan una tensión semántica, una catálisis, que dirige al oyente hacia el drama y, acorde con el discurso, le hace dudar de sus certezas.

b) Unión (Guy-Bruno)

El narrador y la música emitida por el programa de radio, en consonancia con el tono general, pautan esta concatenación de acciones, cuya finalidad dramática es mostrar a los personajes en su entorno familiar y señalar la conveniencia del pacto. El acompasado ritmo con el que se suceden estas escenas, como si del traqueteo del tren se tratara, expresa metonímicamente la idea que anima esta unidad, la conveniencia del pacto. No casualmente, se abre y se cierra con Anne. Primero con su padre en el club Astorga: sus diálogos, música y ambiente son la imagen de una vida llena de lujos a la que Guy sólo tendrá acceso con el éxito. Guy constata la imposibilidad de alcanzarlo al rechazar el encargo del Palmira club. Anne le anima: «No te preocupes, todo va a salir bien».

Entre ambas escenas, la voz de Bruno, al acecho, le recuerda el pacto: «Ya sé lo que voy a hacer», dice mientras su madre se aleja -segundo plano sonoro- y pide a la telefonista el número de Miriam. El timbre del teléfono sube a primer plano dando paso a la música extradiegética que suspende el sentido, dejando abierto el enigma que está próximo a resolverse. Anne representa una vida de lujos a la que Guy sólo tendrá acceso dando la espalda a su pasado, es decir, a la desaparición de Miriam. De este modo, se establece un juego perverso entre las dulces palabras de Anne y 
los sentidos opuestos que se abren con ella, pues sabemos que Bruno se dirige hacia Metcalf para cumplir el pacto. Anne y Bruno simbolizan las dos caras de Guy.

\subsection{Tercera unidad: El encuentro con la verdad ${ }^{17}$}

Un sistema oposicional abre esta unidad y, con él, se dan cita códigos de diferente procedencia. Tras incidir en el estado de borrachera en el que se encuentra Bruno - «La media botella de scotch le quitó la resaca»-, el narrador plantea un deprimente panorama: en el porche un gordo abanicándose, dos mujeres en una mecedora, un ventilador.

El hastío, la quietud y el calor, indicios que señalan hacia una ciudad de provincias sureña y los prejuicios de clase, expresados a través de los pensamientos de Bruno -«No podía imaginar un escenario mejor para Miriam»-, contrastan con la algarabía del parque de atracciones al que se dirige Miriam con sus amigos: el escenario del crimen, donde todo en él es acción y movimiento, cuyo aire fresco le anuncia una gran noche.

Esa voz del narrador desdoblada, que va intercalando sus pensamientos con las acciones, conduce siempre hacia una misma idea: el asesinato. Y está construida a través de figuras poéticas, en las que se dan cita los cinco sentidos, para confluir, como una explosión, en este gran momento tras el cual «Bruno se sentía inmensamente feliz».

Las figuras visuales se muestran al montarse en el tiovivo, siguiendo a Miriam y sus amigos: «con la boca abierta, Miriam parecía fea y estúpida». Daba la impresión de que la estaban estrangulando. Tenía el rostro encarnado e hinchado. Momentos antes del asesinato: Miriam era una mancha «negra y fea». «Bruno saltó con sus manos abiertas y las muñecas pegadas una a la otra».

Las figuras sonoras aparecen cuando entran en el parque. Si entonces la música le anunciaba «una gran noche», previamente al crimen «sonaba cansina»; dando paso a la retransmisión de un combate de boxeo por radio, mientras Bruno veía a una pareja revolcándose como si ellos también estuvieran luchando. La pared latía rítmicamente delante de sus ojos como a punto de saltar en pedazos, asesinato.

Las figuras olfativas están representadas por el olor del perfume dulzón, que le pareció repulsivo. Al ver a Miriam, percibió el perfume y éste le conduje hacia ella.

Las figuras táctiles se dan tras el asesinato.: «la saliva se le quedó en las manos». Después se limpia con el pañuelo y lo tira pero lo recoge porque llevaba sus iniciales. «Pensaba en todos los detalles».

\subsubsection{El filme}

Reproduce con fidelidad las acciones y escenarios de la novela. Opone el porche donde algunas personas soportan el hastío de una noche calurosa de verano al parque de atracciones, luminoso y lleno de gente que deambula. En consecuencia

17 Función: Supone el clímax dramático y, consecuentemente, la resolución (parcial) del enigma. Ese campo semántico creado al iniciar el relato, alrededor de la paradoja, estalla en una explosión de sentidos para sumergirnos en la verdad. Acciones: Un recorrido que conduce del juego de la seducción al asesinato. 
nos conduce hacia esa antítesis que inunda el relato, confiriéndole sentido.

La secuencia está organizada alrededor de la seducción, un juego de miradas entre Miriam y Bruno que, de nuevo, escenifica aquello que las apariencias no dejan ver. Ahora se dirige inevitablemente hacia la verdad, con la resolución (parcial) del enigma. Una serie de dilataciones temporales (catálisis) suspenden el sentido último, la muerte, mientras el espectador asiste a los acontecimientos impasible y, aunque sabe el final, apoya a Bruno en ese intercambio de miradas, pues como Guy (y por eso secretamente) desea su muerte.

Si las palabras de Bruno resonaban en la unidad anterior desvelando su rabia y, por ende, sus deseos, ahora son las palabras de Guy - «La mataría con mis propias manos»)-, las que acuden como un eco a esta unidad en la que la verdad hace su entrada.

Articulada en torno a este juego, la puesta en escena va dilatando el tiempo ${ }^{18}$ en una suerte de viaje -se inicia en el autobús que conduce a Miriam y sus amigos hacia el parque, seguidos por Bruno- cuyo destino ya está fijado. La perversidad inherente en el cruce de miradas entre Bruno, que agazapado observa o participa de las atracciones, y Miriam, que coquetea con sus dos amigos mientras toman helados, va creciendo a medida que nos acercamos al destino final. Tras montar en El túnel del amor, donde los gritos de Miriam se transforman en risas, se dirigen en barca a la isla, escenario del crimen. Es Miriam quien provoca quedarse a solas con Bruno que, tras preguntarle su nombre, la agarra por el cuello hasta matarla. Clímax dramático anunciado en este juego de miradas perverso que, consecuentemente, acaba en un reflejo, pues todo el asesinato es visto desde el cristal de las gafas de Miriam que en el forcejeo caen al suelo, junto con el mechero.

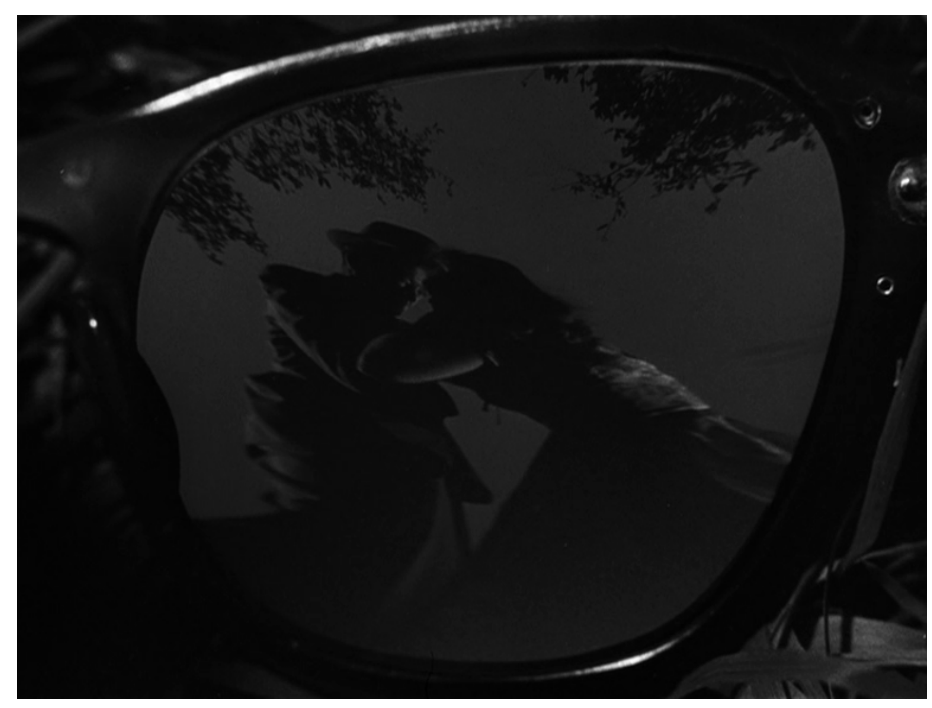

Imagen 3. Asesinato visto a través del cristal de las gafas de Miriam. 


\subsubsection{La ficción sonora}

¿Cómo consigue efectuar la transposición en esta unidad dramática que apenas tiene una línea de diálogo? ¿Qué imágenes sonoras se utilizan?

Esa configuración oposicional, acorde con el universo simbólico, inunda el discurso ahora hacia el encuentro con la verdad, provocando la resolución del enigma.

Siguiendo con la lógica del relato, un narrador sitúa la acción: «Metcalf, 7 de la tarde». Plantea esta unidad, lo mismo que el filme, un juego perverso. Partiendo de la realidad de Guy: «Todo va a salir bien», le dice Anne, ante el temor a ser rechazado por su padre. Tras esto, el frenazo de un coche da entrada a las palabras de Bruno, siempre malhumorado. Estas dos voces, intercaladas con el estridente frenazo, crean una imagen que acompañará a esta unidad, expresión de la paradoja en la que se sumerge el relato. Voces cuyos sentidos fluyen por el universo de Hitchcock conduciéndonos hacia ese rostro de Guy sobreimpresionado con la manos de Bruno. Estas voces, y por ende sus sentidos, vuelven a aparecer momentos antes del asesinato: Mientras Bruno persigue a Miriam por el parque urdiendo un plan, en montaje paralelo, Guy, que ha rechazado trabajar en el Palmira -a causa de Miriam-, intenta infructuosamente ser aceptado por el padre de Anne. Ahora es la música del tiovivo la que, subiendo a primer plano, da entrada a Miriam, que con voz seductora le dice: «He visto antes como me mirabas». Después de los jadeos, forcejeos y gritos Bruno, con voz contundente le responde: "Ya no vas a amargarle la vida a nadie más». La música extradiegética sube a primer plano y da paso al timbre del teléfono que anuncia a Guy la muerte de Miriam. De nuevo la música en primer plano da la entrada al narrador que evidencia las consecuencias: «Obras en el Palmira Club: cuatro meses después».

De esta forma nos encontramos con dos realidades que se dan cita en el tiempo. Ambas, con su propio arco dramático, crean una secuencia elemental con tres funciones: apertura, actualización y clausura (Bremond, 1970). Una que nos acerca a esa realidad sustentada en las apariencias y que muestra la conveniencia del crimen, cuya secuenciación sería así: apertura -«Todo va a salir bien»-, actualización -el padre de Anne se opone a Guy- y clausura -obras en el Palmira-. Otra que nos acerca a la verdad. Es aquí donde se construye la mayor parte de esta unidad dramática. Su secuencialización sería como sigue: apertura -el frenazo de un taxi da entrada a Bruno, cuyas palabras contrastan con el tono campechano del taxista y la algarabía de Miriam y sus amigos-; actualización -Bruno les sigue en sus paseos por las atracciones del parque-; clausura -en la isla tiene lugar el crimen (es aquí donde se produce el montaje paralelo)-.

En esta tercera unidad aflora otra realidad en la que se cumplen los deseos ocultos de Guy -sucede durante la noche-. Bruno le saca de esa caverna platónica para hacer estallar la verdad. Pero la verdad debe permanecer oculta bajo el manto de las apariencias para que la realidad pueda seguir su curso.

\section{A modo de conclusión}

$\mathrm{Al}$ iniciar este recorrido nos preguntábamos cómo se crea el paisaje sonoro de esta adaptación, de dónde proceden sus imágenes y en qué medida es deudora del filme. 
Llegados a este punto podemos afirmar que, si bien los sistemas expresivos utilizados en la transcodificación para crear ese paisaje sonoro se alimentan del texto fuente, las huellas del universo de Hitchcock se dejan sentir en la construcción de la ficción, contribuyendo a la creación de imágenes sonoras que le confieren una gran carga expresiva.

Conviene incidir en que el tiempo de la diégesis -Estados Unidos, 1950- tiene una función capital en el relato sonoro pues, además de su función narrativa creando continuidad, ayudando en la consecución de las acciones--, contribuye en la recreación del universo simbólico de la novela. En consecuencia, podemos señalar que la adaptación radiofónica de Extraños en un tren se sumerge en ese fluir de significación producido en el cruce entre la novela y el filme, creando una retórica propia del medio que explora el lenguaje, cargada de imágenes que concitan palabras y estas nos llevan a figuras literarias, cinematográficas y, precisamente por eso, devienen paisajes sonoros. Estamos hablando de las transformaciones inherentes en la adaptación y la poética presente en la propia naturaleza del discurso.

La comunión entre la novela y el filme es tal, que en ocasiones el cine se hace literatura, y ésta parece cine. Y es justamente esta interrelación la que enriquece la ficción sonora, multiplicando sus sentidos -en una suerte de recircunstancialización-: la tensión implícita en el texto escrito, las dudas de Guy y las certezas de Bruno y su inmersión en la paradoja. Pero también el pulso dramático del filme, sus imágenes: los escenarios, las catálisis creadas con efectos sonoros del tren, el rácord entre las escenas, su ritmo pausado y vertiginoso, su universo poético, en suma.

\section{Bibliografía}

Álvarez Muro, A. (2008). Poética del habla cotidiana. Mérida: Consejo de publicaciones de la Universidad de Los Andes.

Aumont, J. (1992). La imagen. Barcelona: Paidós Comunicación.

Balsebre, A. (1994). El lenguaje radiofónico. Madrid: Cátedra.

Barthes, R. S/Z. (1980). Madrid: Siglo XXI editores.

Barthes, R. (1970). «Introducción al Análisis estructural del relato». En R. Barthes; J. Greimas y C. Bremond (Ed.), Análisis estructural del relato. Buenos Aires: Tiempo Contemporáneo.

Bremond, C. (1970). «La lógica de los posibles narrativos». En R. Barthes; J. Greimas y C. Bremond (Ed.), Análisis estructural del relato. Buenos Aires: Tiempo Contemporáneo.

Bazin, A. Qué es el cine (1990). Barcelona: Ediciones Rialp.

Chávez, R. (2016). Intertextualidad, transgeneración y recircunstancialización en la práctica del remake de 'Salón México'. Tesis doctoral. Universidad de Valladolid.

Flores Mercado, B. G. (2014). «Memoria colectiva, región sociomusical y bandas de viento en Totolapan, Morelos». Cuicuilco. Revista de ciencias antropológicas, 21, 61, pp.189210.

García Arance, R. (1983). La imagen literaria. Valladolid: Secretariado de Publicaciones, Universidad de Valladolid.

García Berrio, A. (1994). Teoría de la literatura. La construcción del significado poético. Madrid: Cátedra.

Gauthier, G. (1996). Veinte lecciones sobre la imagen y el sentido. Madrid: Cátedra.

Genette, J. (1989). Palimpsestos. La literatura en segundo grado. Madrid: Taurus. 
Halliday, M. y Hassan, R. (1990). Language, Context and Text: Aspects of Language in a Social-Semiotic Perspective. Oxford: Oxford University Press.

Highsmith, P. (1986). Suspense. Cómo se escribe una novela de intriga. Barcelona: Editorial Anagrama.

-1986 Highsmith, P. Extraños en un tren. Barcelona: Anagrama.

Jakobson, R. (1985). Ensayos de lingüística general. Barcelona: Planeta Agostini.

Kristeva, J. (1997). «Bajtín, la palabra, el diálogo y la novela». En D. Navarro (Ed.), Intertextualité: Francia en el origen de un término y el desarrollo de un concepto. La Habana: UNEAC.

Miguel Borrás, M. (2008). «La poética del cine». En M. Miguel, J. Bermejo y M. Canga (Ed.), Siete miradas, una misma luz. Teoría y análisis cinematográfico. Valladolid: Servicio de Publicaciones Universidad de Valladolid, pp. 71-100.

Morin, E. (1972). El cine o el hombre imaginario. Barcelona: Seix Barral.

Romo, C. (1997). «Lenguaje seductor de la radio». Primer Congreso Internacional de lengua española. Universidad Jesuita de Guadalajara. México. Recuperado de http:/quijote. biblio.iteso.mx/catia/CONEICC/cat.aspx?cmn=browse\&id=10048 (Fecha de acceso: 01/09/2016).

Murray Schafer, R. (2013). El paisaje sonoro y la afinación del mundo. Bogotá: Intermedio. Saussure, F. (1973). Curso de linguística general. Madrid: Losada.

Truffaut, F. (1974). El cine según Hitchcock. Madrid: Alianza Editorial. 